\title{
The Possible Therapeutic Role of Platelet Rich Plasma on a Model of Osteoarthritis in Male Albino Rat. Histological and Immunohistochemical Study
}

Original Article

\author{
Nebal Gamal, Naglaa M. Abou-Rabia, Faika H. El Ebiary, Gehan Khalaf and \\ Mona H. Raafat
}

Department of Histology and Cell Biology, Faculty of Medicine, Ain Shams University.

\begin{abstract}
Introduction and Aim of the Study: Osteoarthritis (OA) is a degenerative joint disease characterized by joint pain and progressive loss of articular cartilage. This study was conducted to evaluate the therapeutic effect of platelet-rich plasma (PRP) on the knee joint in a rat model of OA.

Materials and Methods: Forty adult male albino rats, weighing 200-250 gm, were used in this study, ten rats used as donors to obtain PRP. The other thirty rats were divided into two main groups. Group I: The control group (15 rats) in which the rats were subdivided into three subgroups. Subgroups IA and IB were sacrificed 4 and 6 weeks after the beginning of the experiment. Subgroup IC left for 4 weeks then received intra-articular injection of PRP in the right knee joint which was repeated three times per week for 2 weeks then the animals were sacrificed. Group II (The experimental group) (15 rats) in which OA was induced by surgical induction of cartilaginous defect in the right knee joints. The rats of group II were subdivided into three subgroups. Subgroups IIA and IIB were sacrificed 4 and 6 weeks after induction of OA respectively. Subgroup IIC received intra-articular injection of PRP $(0.2 \mathrm{ml})$ in the right knee joints 4 weeks after surgery. The injection was repeated three times per week for 2 weeks then the animals were sacrificed. The right joints from all groups were collected, decalcified and processed for histological studies. Specimens were also processed for transmission electron microscopic study. Morphometric and statistical measurements were done.

Results: Histological examination of the right knee joints of OA groups (subgroups IIA and IIB) resulted in thickening of the intimal lining of the synovial membrane, cellular infiltration, increased collagen content of the subintimal and moderate expression of platelet derived growth factor (PDGF). The articular cartilage showed surface erosions, thinning of cartilage, chondrocytes and ground substance loss. Injection of PRP resulted in improvement of the structure of the articular cartilage and the synovial membrane with strong expression of PDGF.

Conclusion: Intra-articular injection of PRP resulted in a significant improvement in the histological structure of the knee joint in a rat model of $\mathrm{OA}$.
\end{abstract}

Received: 18 February 2019, Accepted: 09 March 2019

Key Words: Knee joint, osteoarthritis, platelet rich plasma, synovial membrane.

Corresponding Author: Mona H. Raafat, PhD, Histology and Cell Biology, Faculty of Medicine, Ain Shams University. Cairo, Egypt, Tel.: +20 1005223587, E-mail: mona.raafat@med.asu.edu.eg

ISSN: $1110-0559$, Vol. 42 , No. 3

\section{INTRODUCTION}

Osteoarthritis is a degenerative joint disease characterized by joint pain and progressive loss of articular cartilage ${ }^{[1]}$. About $80 \%$ to $90 \%$ of individuals have evidence of osteoarthritis by the time they reach age $65^{[2]}$. Osteoarthritis mostly affects the weight-bearing joints, like the knee, hips, cervical, lumbar and sacral spines $^{[3]}$. Meanwhile, some investigators ${ }^{[2]}$ postulated that primary OA is related to aging. The pathophysiology involves mechanical, cellular and biochemical processes. The interaction of these processes causes changes in the composition and mechanical properties of the articular cartilage. With aging, the water content of the cartilage decreases as a result of decrease in the proteoglycans causing the cartilage to become less resilient. On the other hand, the secondary OA may be due to congenital disorder, obesity, inflammatory conditions like rheumatoid arthritis, metabolic disorders like haemochromatosis, endocrine diseases like diabetes, marfan syndrome and injury to joints or ligaments ${ }^{[4]}$.

Platelet rich plasma (PRP) has recently attracted interest in many medical specialties. It is defined as a plasma fraction that contain a higher concentration of platelets than the peripheral blood ${ }^{[5]}$. PRP contains a hyper-physiological content of growth factors ${ }^{[6]}$. The regenerative capacity of PRP is attributed to at least fifteen different factors that are known to be contained within platelets ${ }^{[7]}$, including plateletderived growth factor (PDGF), transforming growth factor $-\beta$ (TGF- $\beta$ ), vascular endothelial growth factor (VEGF), epidermal growth factor, and insulin growth factor (IGF). Most of these factors have been demonstrated to influence cartilage healing and regeneration ${ }^{[8]}$. Platelet rich plasma 
is used for treatment of alopecia, diabetic foot ulcer, rupture of tendoachillis, atrophic acne scars and dermal degeneration ${ }^{[9]}$. In addition, it has an antimicrobial activity, so it is used in treating infected wounds to promote healing. PRP has been proved to be safe and effective as hyaluronic acid in improvement of osteoarthritis ${ }^{[10]}$.

\section{AIM OF THE WORK}

There is an urgent need for trials to develop more effective strategies for treating the disabling disorders of osteoarthritis. Therefore, the aim of this study was to evaluate the possible therapeutic role of platelet rich plasma on a model of osteoarthritis in albino rat knee joint.

\section{MATERIALS AND METHODS}

Forty adult male albino rats, weighing 200-250 gm their ages ranged from 4-5months were purchased and housed in the animal house of the Medical Research Center, Faculty of Medicine, Ain Shams University. They were maintained under standard laboratory conditions: $12 / 12$ light/dark cycle and at a room temperature of $28^{\circ} \mathrm{C}$. They were allowed free access to standard rat chow diet and water ad libitum. All animal procedures were performed in accordance with the Guide for the Care and Use of Laboratory Animals and were approved by the Animal Ethical Committee of Ain Shams University.

\section{Animal grouping}

Forty adult male albino rats, weighing 200-250 gm, their ages ranged from 4-5months were used in this study, ten rats were used as donors to obtain PRP. The other thirty rats were divided into two main groups. Group I: The control group (15 rats) in which the rats were subdivided into three subgroups. Subgroups IA and IB which were sacrificed 4 and 6 weeks after the beginning of the experiment respectively. Subgroup IC was left for 4 weeks then received intra-articular injection of PRP $(0.2$ $\mathrm{ml})$ in the right knee joint. PRP injection was repeated three times per week for 2 weeks ${ }^{[9]}$ then sacrificed. Group II: The experimental group (15 rats) in which OA was induced by surgical induction of cartilaginous defect in the right knee joints. The rats were subdivided into three subgroups. Subgroups IIA and IIB which were sacrificed 4 and 6 weeks after induction of OA respectively. Subgroup IIC received intra-articular injection of PRP $(0.2 \mathrm{ml})$ in the right knee joints 4 weeks after surgery, the injection was repeated three times per week for 2 weeks ${ }^{[9]}$ then the rats were sacrificed.

At the end of the experiment, all animals were sacrificed by decapitation after ether inhalation anesthesia. The right knee joints were dissected, trimmed of skin and muscles (soft tissues). The joints were processed for different histological and immuno-histochemical studies.

\section{Preparation of Platelet Rich Plasma (PRP)}

Two milliliters of blood were collected from the retroorbital vein of each animal into a sodium citrate tubes. The tubes were centrifuged at $1240 \mathrm{rpm}$ for eight minutes. The tubes showed three different density compartment, the lower red blood cells, the middle buffy coat of white blood cells, and the top plasma. The plasma had three distinct layers in ratio of 2:1:1 from the top. The first top layer was platelet poor plasma (PPP), the middle plasma average platelet (PAP) and the lower platelet rich plasma (PRP). The first (PPP) and the second (PAP) were removed by pipette. The third (PRP) layer was carefully separated by pipette and centrifuged again for 5 minutes at the same speed. Then the first layer (plasma) was discarded and the second layer (PRP) was collected ${ }^{[11]}$.

\section{Surgical induction of osteoarthritis}

Induction of cartilaginous defect was done in the right knee joint by scratching the cartilage using sterile needle 28 -guage syringe (Ameco). In maximal flexion, the needle was inserted in joint space from anterior surface and a defect of about $1 \mathrm{~mm}$ width and $2 \mathrm{~mm}$ depth was created mechanically in the articular cartilage of the weightbearing surface of the medial femoral condoyle. The cartilage defect was chondral defect without penetration of the subchondral bone which was confirmed by complete absence of bleeding ${ }^{[12]}$.

\section{A) Histological assessment}

\section{Processing of the right knee joint specimens for light microscopic study}

The animals were sacrificed, and the right knee joints were dissected out. Specimens were processed and prepared for light microscopic study and immunohistochemistry. The specimens were fixed in 10\% formaldehyde and decalcified using ethylene-diamin-tetra-acetic acid (EDTA) in the form of its disodium salt. EDTA solution was prepared as $5.5 \mathrm{~g}$ of EDTA dissolved in a mixture of $90 \mathrm{ml}$ distilled water and $10 \mathrm{ml}$ formaldehyde, 37: $40 \%$. Daily change of the solution was done for six weeks until softening of specimens was obtained. Then they were dehydrated in ascending grades of alcohol, cleared in xylene, embedded in paraffin and sagittal sections of $5 \mu \mathrm{m}$ thickness were cut and stained by H\&E, Mallory trichrome ${ }^{[13]}$, Toluidine Blue $^{[14]}$. Immunohistochemical staining for the detection of platelet derived growth factor (PDGF) ${ }^{[13]}$.

\section{Immunohistochemical technique}

Paraffin sections were stained using an immunoperoxidase technique for the detection of platelet derived growth factor (PDGF): primary goat polyclonal anti-PDGF antibody (R\&D Systems Inc., Minneapolis, MN 55413, USA; catalog no. AF1560). Paraffin sections were deparaffinized, rehydrated then treated in $3 \% \mathrm{H}_{2} \mathrm{O}_{2}$ for $5 \mathrm{~min}$ and washed with phosphate buffer solution (PBS) for $15 \mathrm{~min}$. The sections were blocked with $1.5 \%$ normal goat serum in PBS and then incubated for $45 \mathrm{~min}$ at room temperature with the primary antibody. Sections were subsequently incubated with a second-stage biotinylated antibodies (Biotinylated goat anti-rabbit IgG, Spring Bioscience, catalog no. DGR-125) at room temperature. 
After rinsing in PBS, the reaction products were visualized by immersing the section into diaminobenzidine. Finally, the sections were counterstained with hematoxylin, dehydrated, covered and examined. For negative controls, incubation was carried out by a non-specific IgG antibody at the same concentration as the primary antibody ${ }^{[13]}$.

\section{Preparation of the knee joint specimens for transmission electron microscopic study}

Specimens from the right knee joint of two rats from each group were used for transmission electron microscopic (TEM) examination. The skin, muscle, fatty tissues, and tendons were removed immediately after sacrificing the rats. Samples were trimmed of excessive subchondral bone and cut into $1 \times 1 \times 1 \mathrm{~mm}$ slab. Specimens were fixed in phosphate-buffered formal glutaraldehyde $(2.5 \%)$ in $0.1 \mathrm{~mol} / 1$ for 2 days at $4^{\circ} \mathrm{C}$. Decalcification was achieved by treating the samples with $5 \%$ trichloroacetic acid for 7 days. The samples were rinsed in phosphate buffer for $24 \mathrm{~h}$ and then post-fixed with $1 \%$ osmium tetroxide solution. They were washed four times with phosphate buffer, dehydrated through a graded series of ethanol, and embedded in epoxy resin. Polymerization was performed at $60^{\circ} \mathrm{C}$ over $48 \mathrm{~h}$. One-micrometer-thick sections were cut using an ultramicrotome (Leica Ultra cut UCT; Leica, Wetzlar, Germany) with a glass knife and stained with toluidine blue. Ultrathin sections $(<100 \mathrm{~nm})$ were cut using an ultramicrotome with a diamond knife. Ultrathin sections were taken on a copper grid and stained with uranyl acetate and lead citrate and examined using a TEM (Jeol 1010 EX II; Jeol, Tokyo, Japan) at the regional Mycology and Biotechnology Center, Al-Azhar University ${ }^{[13]}$.

\section{B) Morphometric study and statistical analysis}

\section{Morphometric measurements include}

1. The mean values of cartilage thickness at a magnification $\mathrm{x} 100$.

2. The mean area percentage of collagen fibers at a magnification x 200 .

3. The mean color density of toluidine blue stain at a magnification x 200 .

4. The mean color density of platelet derived growth factor expression at a magnification $\mathrm{x} 400$.

All measurements were taken using the image analyzer leica (Q 500 MC program, Wetzlar, Germany) at Histology Department, Faculty of Medicine, Ain Shams University, Cairo, Egypt. Data were collected by examining five highpower fields per different sections from each group. All values of the morphometric results were expressed as mean \pm standard deviation. Statistical analysis was carried out using Statistical package for the social sciences (SPSS), software program, version 20 (IBM Corporation, Armonk, North Castle, Westchester county, New York, USA). Statistical difference among groups was determined using two-way analysis of variance (ANOVA) followed by post hoc least significance difference (LSD) for comparison between more than two groups. $P$ values $<0.05$ were considered statistically significant.

\section{RESULTS}

\section{A) Light microscopic study}

Examination of the structure of the right knee joints of the rats of control groups (subgroups IA and IB) revealed similar histological structure, subgroup IC also revealed similar histological structure except immune-histochemical results showed some differences.

Histological examination of H\&E stained sections of subgroup IA revealed that the knee joint consisted of the articular surface of the femur, the articular surface of the tibia and the underlying bone. The joint cavity is lined by the synovial membrane (Figure 1a). The articular cartilage of the knee joint showed a regular smooth surface. The chondrocytes were arranged into four zones: a superficial tangential zone; in which chondrocytes were arranged parallel to the surface, a transitional zone; containing scattered chondrocytes; a radial zone containing chondrocytes with pale basophilic cytoplasm and resident in their lacunae arranged perpendicular to the surface; and a calcified zone separating the cartilage from the underlying subchondral bone. The tide mark separates the radial zone from the calcified zone (Figure 1b). The synovial membrane of the knee joint showed thin intima formed of synovial cells (synoviocytes). The subintimal stroma contained evident fat cells and loose areolar connective tissue (Figure 2a).

The histological examination of H\&E stained sections of OA groups (subgroups IIA and IIB) showed surface erosions of the articular cartilage and a significant decrease $(P<0.05)$ in the thickness of the articular cartilage $(108.68 \pm 5.22)(50.22 \pm 2.6)$ respectively when compared with subgroup IA (457.31 \pm 13.61$)$ (Histogram 1). The zones of the articular cartilage were not clearly defined and there was an apparent focal decrease in the thickness of the articular cartilage as compared to subgroup IA. Areas of chondrocytes loss and other areas showed chondrocytes with pyknotic nuclei. Also, the tide mark was ill-defined with focal interruption (Figures 1c and d). Discontinuity of the matrix was also seen in addition to the previous changes (Figure 1e). Moreover, there was a significant decrease $(P<0.05)$ in the mean cartilage thickness in subgroup IIB (50.22 \pm 2.6$)$ as compared with subgroup IIA (108.68 \pm 5.22$)$ (Histogram 1). The synovial membrane of the knee joint showed thickened fold of intimal lining and infiltration of the subintimal stroma by inflammatory cells (Figures $2 \mathrm{~b}$ and $\mathrm{c}$ ). The articular cartilage degradation and synovial membrane affection was more prominent in subgroup IIB (6 weeks after induction of OA) compared to subgroup IIA (4 weeks after induction of OA).

The histological examination of H\&E stained sections of PRP-treated OA group (subgroup IIC) showed a smooth 
surface of the articular cartilage. The chondrocytes were clearly arranged into a superficial tangential zone, a transitional zone, a radial zone and a calcified zone. The tide mark separates the radial zone from the calcified zone was clearly seen (Figure 1f). Moreover, there was a significant increase $(P<0.05)$ in the mean cartilage thickness in subgroup IIC $(453.59 \pm 15.26)$ compared to subgroups IIA \& IIB (108.68 \pm 5.22$)(50.22 \pm 2.6)$ (Histogram 1). The synovial membrane of the articular cartilage of the knee joint showed an apparent thin intimal lining compared to subgroups IIA and IIB. The subintimal stroma showed evident fat cells and loose areolar connective tissue (Figure 2d).

Mallory stained sections of subgroup IA revealed few scattered collagen fibers in the subintimal stroma (Figure 3a). In the OA groups (subgroups IIA and IIB) there was a significant increase $(P<0.05)$ in the mean area percentage of collagen fibers in the subintimal stroma $(34.73 \pm 2.63)(50.71 \pm 5.86)$ respectively as compared to subgroup IA (2.27 \pm 1.01$)$ (Figures $3 \mathrm{~b}$ and $\mathrm{c}$ ) while the PRPtreated OA group (subgroup IIC) showed a significant decrease $(P<0.05)(2.72 \pm 0.9)$ as compared to OA groups (subgroups IIA and IIB) (34.73 \pm 2.63$) \quad(50.71 \pm 5.86)$ respectively (Figure 3d) (Histogram 2).

Toluidine blue stained sections of the articular cartilage of the knee joint of subgroup IA showed deeply stained cartilage matrix (Figure 4a). In OA groups (subgroups IIA\&IIB) showed a significant decrease $(P<0.05)$ in the mean color density of toluidine blue stain $(77.45 \pm 1.56)$ (73.34 \pm 12.91$)$ respectively as compared to subgroup IA (102.64 \pm 1.86$)$ (Figures $4 \mathrm{~b}$ and $\mathrm{c}$ ), while the PRP treated OA group (subgroup IIC) showed significant increase $(P<0.05)$ in the mean color density of toluidine blue stain $(97.63 \pm 1.58)$ in comparison to OA groups (subgroups IIA and IIB) $(77.45 \pm 1.56)(73.34 \pm 12.91)$ respectively (Figure 4d) (Histogram 3).

Immunostaining of sections of the synovial membrane of the knee joint of subgroup IA with anti-PDGF showed weak expression of color density in the cytoplasm of synoviocytes and in the cytoplasm of vascular endothelium (Figure 5b), while it showed strong expression of color density in subgroup IC (Figure 5c). In OA groups (subgroups IIA and IIB), they showed moderate expression of color density in the cytoplasm of synoviocytes and in the cytoplasm of vascular endothelium as compared to subgroup IA (Figures 5d and e) while in PRP treated OA group (subgroup IIC), it showed strong expression of color density as compared to OA groups (subgroups IIA and IIB) in the form of brown granules (Figure $5 \mathrm{f}$ ). The negative control showed no immune-reactivity (Figure 5a). These results were confirmed by morphometric measurements. There was a significant decrease $(P<0.05)$ in the color density of PDGF expression in subgroup IA (51.46 \pm 1.30$)$ when compared with subgroups IC $(81.85 \pm 2.05)$ and IIC (78.95 \pm 1.25$)$. Similarly, there was a significant decrease $(P<0.05)$ in subgroups IIA $(65.54 \pm 11.69)$ and IIB $(59.48 \pm 2.84)$ as compared to subgroups IC and IIC $(81.85 \pm 2.05)$. (78.95 \pm 1.25$)$ respectively (Histogram 4).

\section{B) Transmission electron microscopic study}

There were no obvious ultra-structural differences between the different control subgroups. Transmission electron microscopic examination of the right femoral articular cartilage of subgroup IA showed chondrocyte inside lacuna. The chondrocyte had euchromatic nucleus and surrounded by regularly arranged collagen fibrils (Figure 6a). In subgroup IIA showed a shrunken chondrocyte with deformed nucleus. The cell membrane was irregular, and the cytoplasm showed multiple vacuoles (Figure 6b). In subgroup IIB, showed two chondrocytes inside their lacunae were seen. One of them showed its nucleus with chromatin margination while the other chondrocyte showed nuclear disintegration. Also, extensive randomly oriented collagen fibrils were observed (Figure 6c). In subgroup IIC, most chondrocytes inside their lacunae (cell nest) with euchromatic nuclei. They are surrounded by regularly arranged collagen fibrils (Figure 6d). 

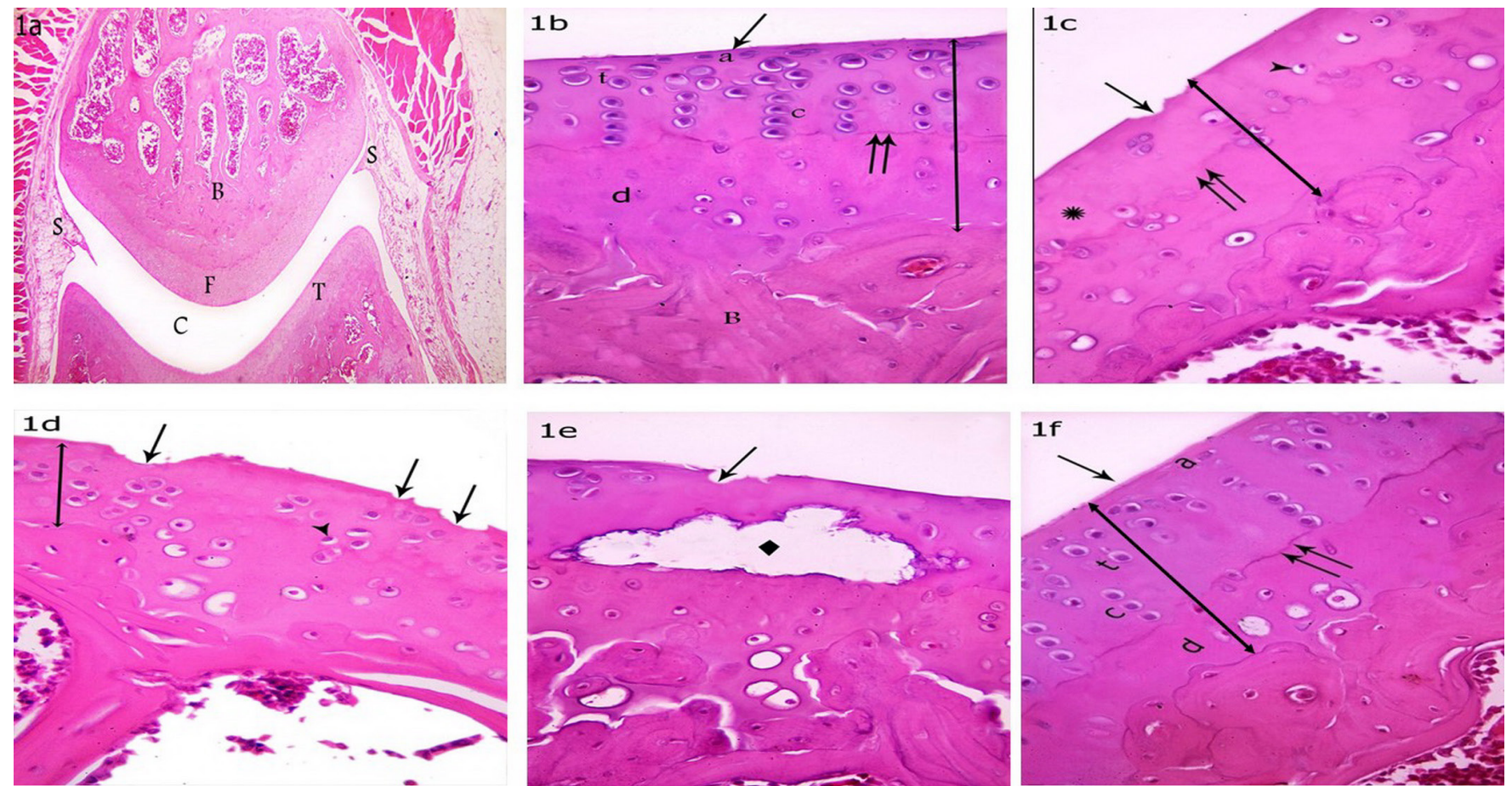

Fig. 1: Photomicrographs of the articular cartilage of the knee joint. [a] Control group [subgroup IA] showing the articular surface of the femur [F], the articular surface of the tibia $[\mathrm{T}]$, the underlying bone $[\mathrm{B}]$, the joint cavity $[\mathrm{C}]$ and the synovial membrane $[\mathrm{S}]$. [b] Control group [subgroup IA] showing a regular smooth surface of the articular cartilage [ $\uparrow]$. The chondrocytes are arranged into four zones: a superficial zone [a]; a transitional zone [t]; a radial zone

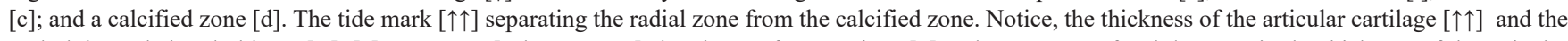
underlying subchondral bone [B]. [c] OA group [subgroup IIA] showing surface erosions [ $\uparrow$ ] and an apparent focal decrease in the thickness of the articular

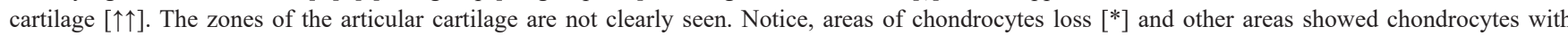

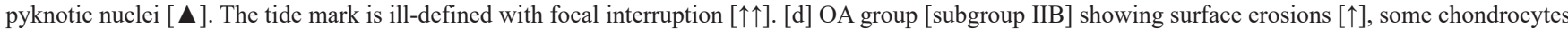

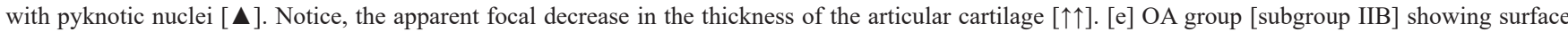

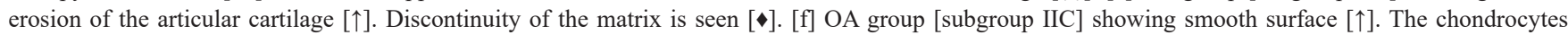

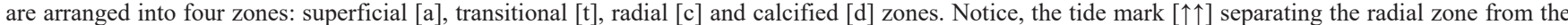

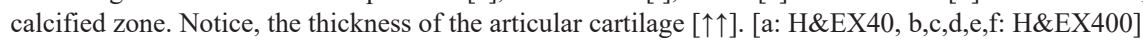
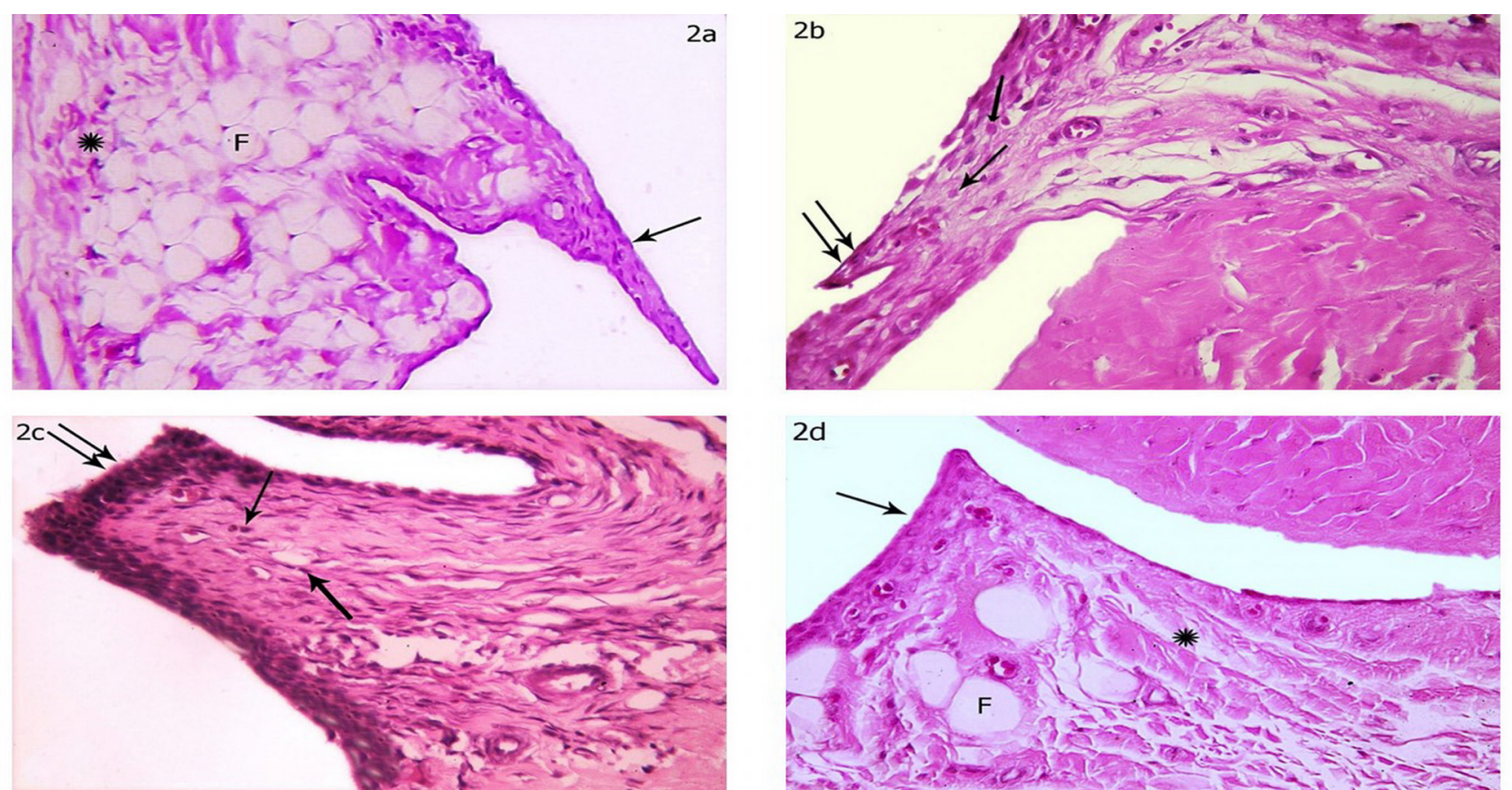

Fig. 2: Photomicrographs of the synovial membrane of the knee joint. [a] subgroup IA showing thin intima formed of synovial cells [个]. The subintimal stroma contains evident fat cells $[\mathrm{F}]$ and loose areolar connective tissue $[*]$. [b] subgroup IIA showing thickened fold of intimal lining $[\uparrow \uparrow]$ and infiltration of the

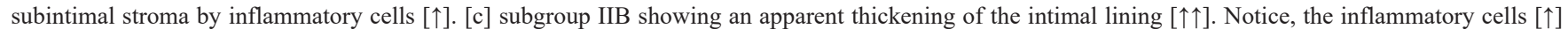
in the subintimal stroma. [d] subgroup IIC showing an apparent thin intimal lining [个]. The subintimal stroma contains evident fat cells [F] and loose areolar connective tissue [*]. [a,b,c,d: H\&EX400]. 
$3 a$

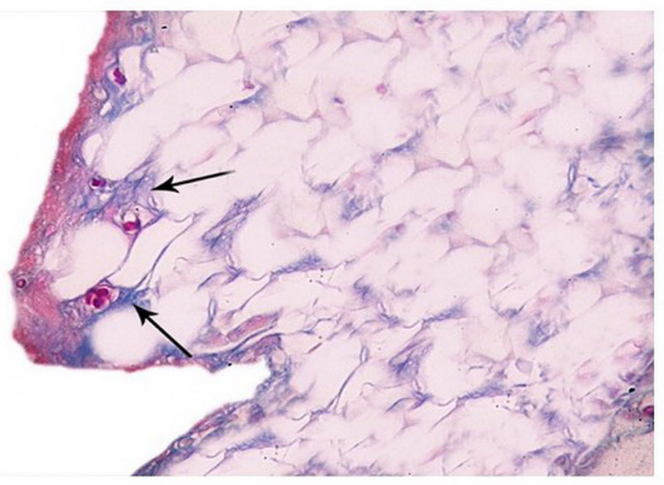

$3 c$

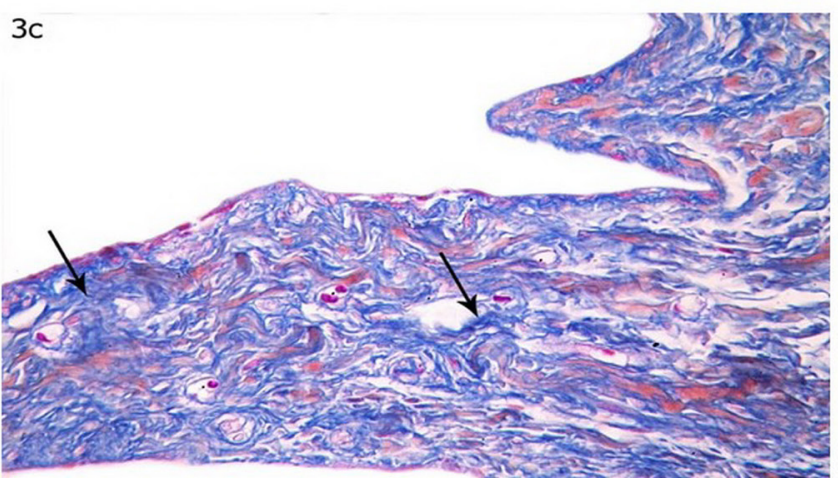

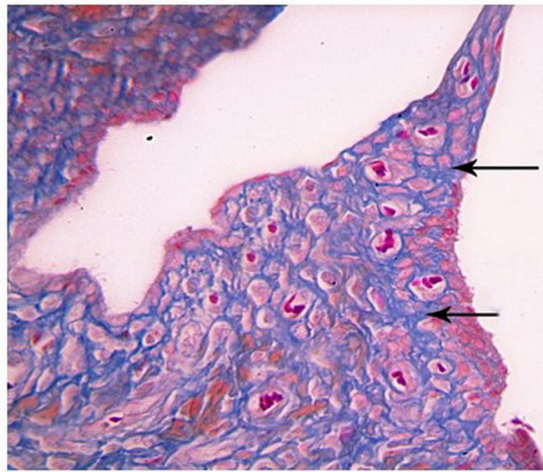

$3 b$

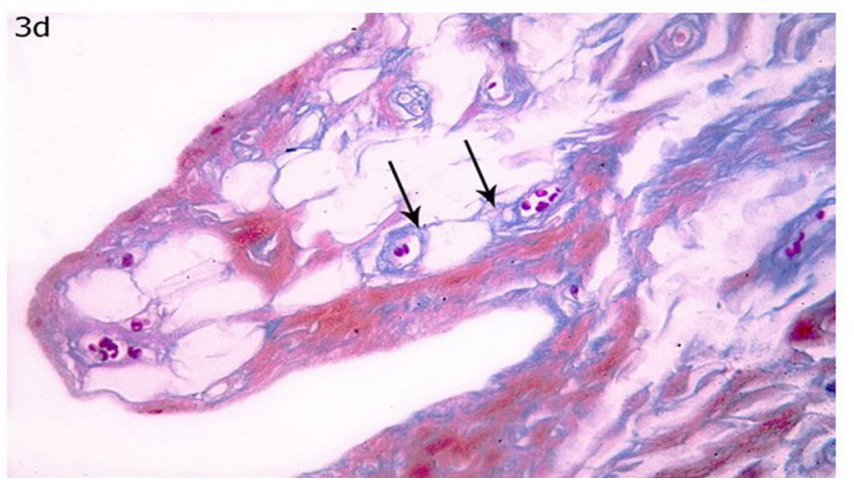

Fig. 3: Photomicrographs of the synovial membrane of the knee joint. [a] subgroup IA showing few scattered collagen fibers in the subintimal stroma [ $\uparrow$ ]. [b\&c] subgroup IIA and subgroup IIB showing abundant collagen fibers in the subintimal stroma [ $\uparrow$ ]. [d] subgroup IIC showing few collagen fibers in the subintimal stroma [个]. [a,b,c,d: Mallory stain X400].
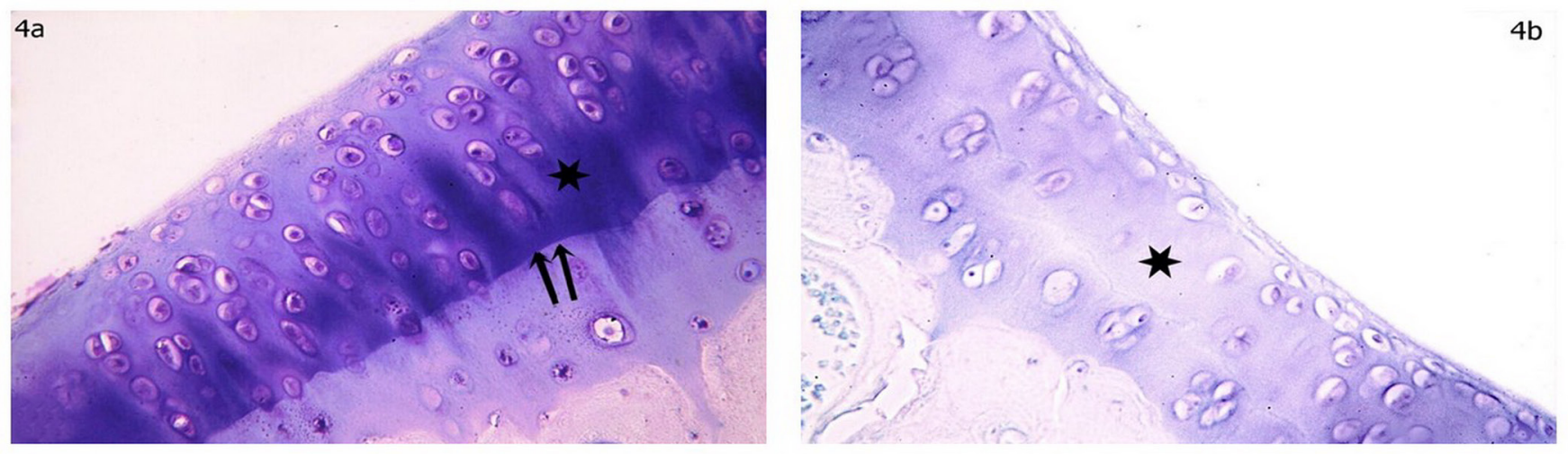

$4 c$

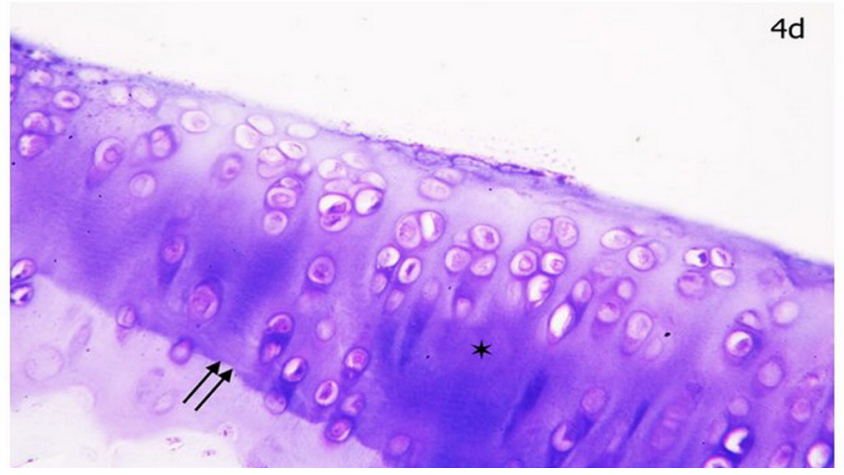

Fig. 4: Photomicrographs of the articular cartilage of the knee joint. [a] subgroup IA showing deep staining of the cartilage matrix [*]. Notice, the tide mark $[\uparrow \uparrow]$ separating the radial zone from the calcified zone. [b\&c] subgroup IIA and subgroup IIB showing faint staining of cartilage matrix [*]. [d] subgroup IIC

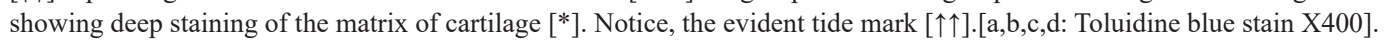





Fig. 5: Photomicrographs of the synovial membrane of the knee joint. [a] The negative control showing no immune-reactivity. [b] subgroup IA showing weak expression in the cytoplasm of synoviocytes of intima [ $\uparrow$ ] and in the cytoplasm of vascular endothelium [ $\mathbf{\Delta}$ ]. [c] subgroup IC showing strong expression in the cytoplasm of synoviocytes [ $\uparrow$ ] and in the cytoplasm of vascular endothelium [ $\mathbf{\Delta}$ ]. [d\&e] subgroup IIA and subgroup IIB showing moderate expression in the cytoplasm of synoviocytes $[\uparrow]$ and in the cytoplasm of vascular endothelium [ $\mathbf{\Delta}]$. [f] subgroup IIC showing strong expression in the cytoplasm of synoviocytes $[\uparrow]$ and in the cytoplasm of vascular endothelial cells [ $\mathbf{\Delta}$ ].[a: Negative control X400, b,c,d,e,f: Anti-PDGF X400].
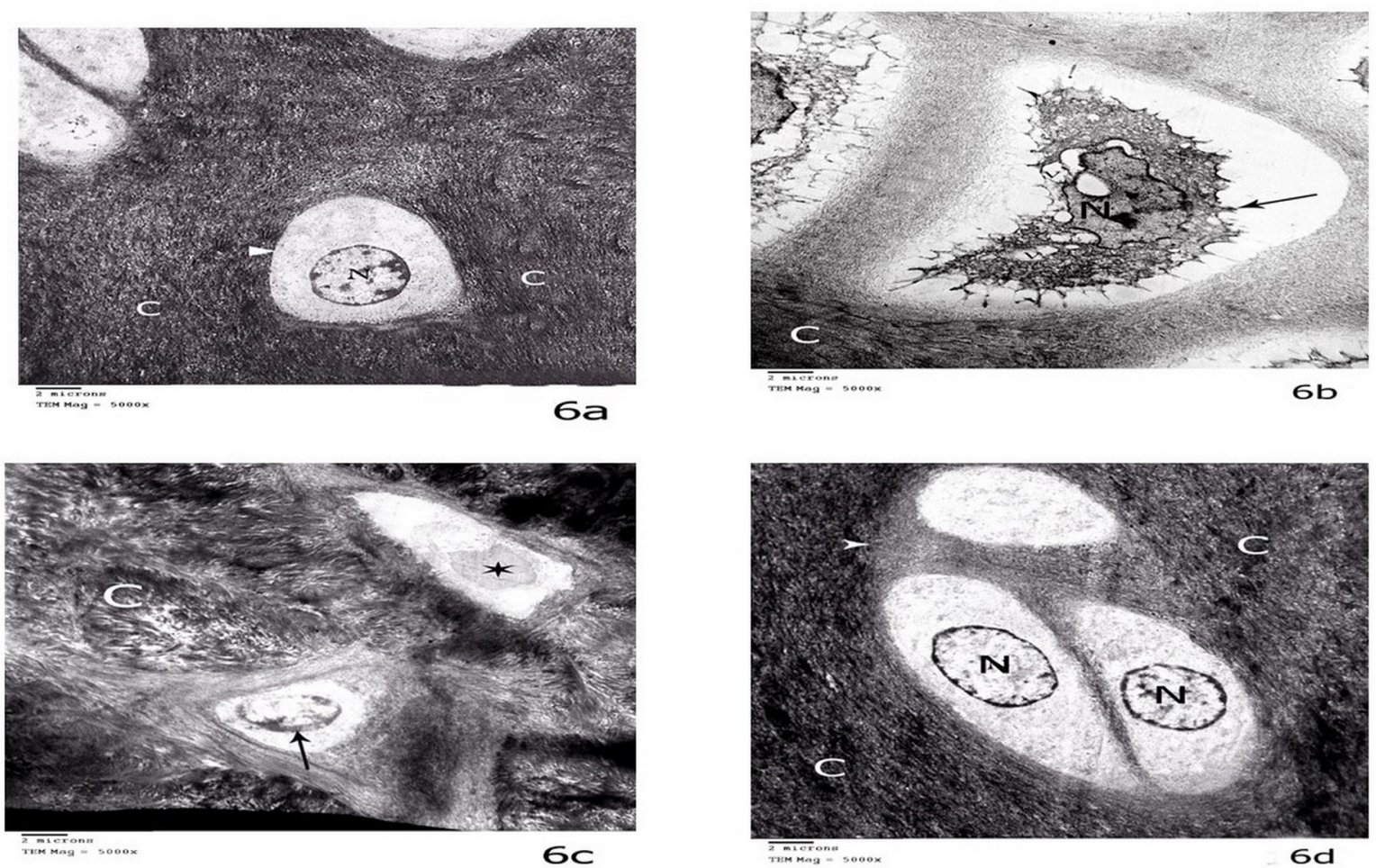

Fig. 6: Transmission electron micrographs of the articular cartilage of the knee joint. [a] subgroup IA showing a chondrocyte inside its lacuna [ $\mathbf{\Delta}$ ]. The chondrocyte has euchromatic nucleus [N]. Notice the surrounding regularly arranged collagen fibrils [C]. [b] subgroup IIA showing a shrunken chondrocyte with deformed nucleus $[\mathrm{N}]$. The cell membrane is irregular $[\uparrow]$ and the cytoplasm shows multiple vacuoles [V]. Notice, the cell is surrounded by regularly arranged collagen fibrils [C]. [c] subgroup IIB showing two chondrocytes, one of them showed its nucleus with chromatin margination [ $\uparrow$ ]. The other chondrocyte showed nuclear disintegration [*]. Notice the extensive randomly oriented collagen fibrils [C]. [d] subgroup IIC showing chondrocytes inside their lacunae [cell nest] [ $\mathbf{\Delta}$ ] with euchromatic nuclei [N]. They are surrounded by regularly arranged collagen fibrils [C]. [a,b,c,d: TEM X5000]. 


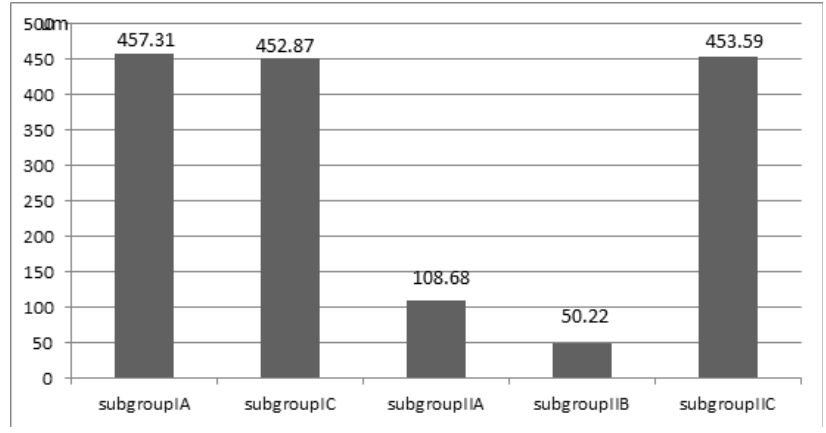

Histogram 1: The mean cartilage thickness in different subgroups.

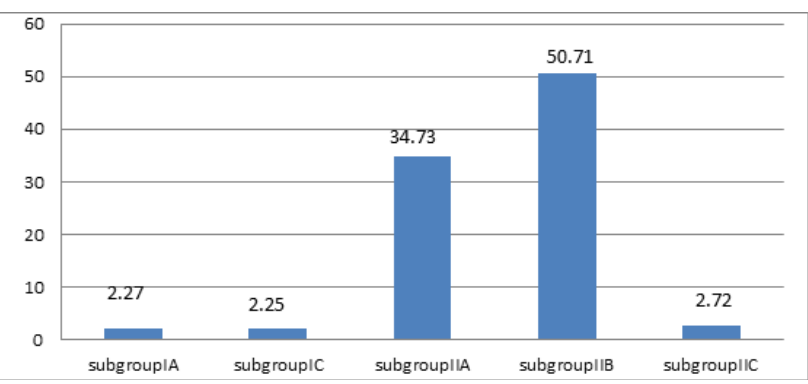

Histogram 2: The mean area percentage of collagen fibers in synovial membrane in different subgroups.

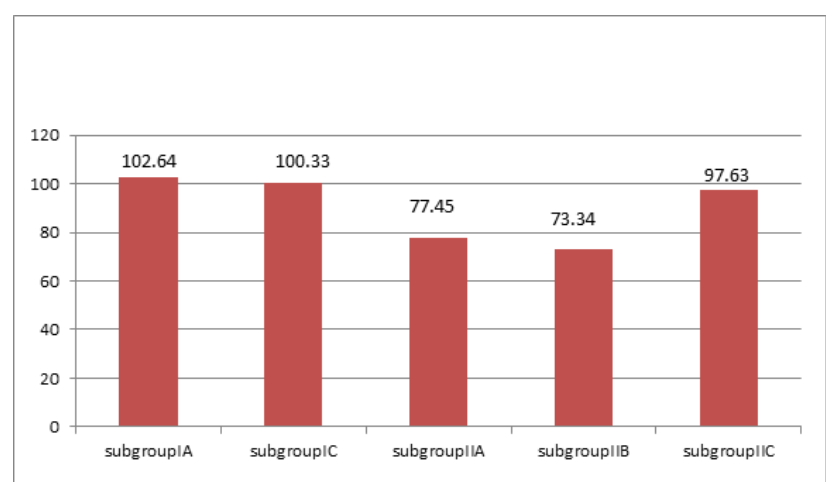

Histogram 3: The mean color density of toluidine blue stain in the articular cartilage in different subgroups.

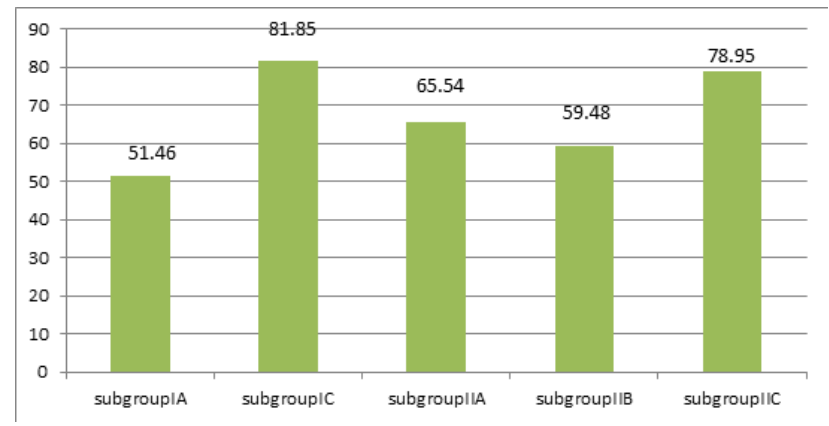

Histogram 4: The mean color density of PDGF expression in synovial membrane in different subgroups.

\section{DISCUSSION}

Osteoarthritis (OA) is one of the most debilitating joint diseases that has major effects on the life style and characterized by cartilage degeneration, loss of joint space and formation of osteophytes ${ }^{[15]}$.
Osteoarthritic experimental model was induced to evaluate the histological changes in cartilage and synovial membrane that occur in this study and to evaluate the possible therapeutic role of PRP on this model of induced osteoarthritis.

The articular cartilage of the knee joint in OA groups (subgroups IIA and IIB) showed an irregular surface with erosions, degenerated chondrocytes, empty lacunae, areas of chondrocytes loss and areas of discontinuity of the matrix. There was also a significant decrease in the thickness of the cartilage as compared to control group (subgroup IA). Various degenerative changes in the chondrocytes were detected by EM examination. These findings were in accordance to other authors who reported that, there was an apparent decrease in articular cartilage thickness in early arthritis. They noticed the presence of cell clusters containing degenerated chondrocytes with pyknotic nuclei ${ }^{[16]}$. The articular surface erosions that were observed in OA model was explained by other authors who stated that the type of the collagen changed from collagen type II to collagen type I. As a result of change of collagen type, the osteoarthritic cartilaginous tissues exhibited a reduced ability to store elastic energy leading to surface discontinuities ${ }^{[17]}$. In addition, it was stated that the chondrocytes digest the matrix by MMPs (matrix metalloproteinases). Consequently, matrix synthesis was inhibited, and erosion of the cartilage was accelerated $^{[3]}$. Similarly, a more recent study notified an apparent decrease in articular cartilage thickness in a rat model of osteoarthritis and suggested that this might be due to cartilage degradation which exceeds synthesis, thus affecting the normal balance ${ }^{[18]}$.

The faint tide mark that was noticed in OA model of the current study was explained by some authors ${ }^{[19]}$ who stated that faint or ill-defined tide mark was attributed to destruction of collagen fibers. Collagen fibers proceed from the calcified cartilage, passing perpendicularly through the tidemark into the uncalcified cartilage. This was in agreement with ${ }^{[20]}$ who found focal interruption and ill-defined tide mark in a rat model of OA treated by hyaluronic acid.

The rats of the OA groups (subgroups IIA and IIB), showed a decrease in the color density of toluidine blue stain of the cartilage matrix which was more prominent 6 weeks after $\mathrm{OA}$ induction. This indicated a decrease in the proteoglycan content of cartilage matrix. In agreement to these results, other authors reported that the proteoglycan loss was an early marker of cartilage degradation ${ }^{[16]}$ in a rat model of induced rheumatoid arthritis.

Four and six weeks after OA induction (subgroup IIA and IIB), the synovial membrane showed thick intima, cellular infiltration of subintima and abundant collagen fibers. This was in agreement with other authors who found that the intima of the synovium of OA rats' joints was formed of multiple layers of synoviocytes while the subintima showed an increase in the inflammatory cells ${ }^{[9]}$. Moreover, the 
synovial membrane thickening was attributed to infiltration by macrophage, lymphocytes, plasma cells and synovial fibroblast cells, these studies was done to compare the macroscopic and microscopic characteristics of synovial tissue in rheumatoid arthritis and $\mathrm{OA}$ in patients ${ }^{[21]}$. The inflamed synovium produced pro-inflammatory cytokines such as tumor necrosis factor (TNF- $\alpha$ ) and interleukin-1 (IL-1) which were bound to chondrocytes receptors' causing release of MMPs and inhibiting production of type II collagen, hence enhancing cartilage degradation ${ }^{[22]}$. Moreover, the chronic inflammation of the synovial membrane led to increase production of the nitric oxide (NO) from inflammatory cells (macrophages) and endothelium. Nitric oxide might cause hypoxia that led to increase permeability to macromolecules facilitating edema formation and cell extravasations. This could explain the cellular infiltration noticed in OA group ${ }^{[23]}$. Also, hypoxia might induce synovial angiogenesis that subsequently guides pro-inflammatory mediators to the synovium along with the new blood vessels ${ }^{[24]}$. Moreover, the NO might be responsible for activation of MMPs and inhibition of synthesis of collagen and proteoglycan which led to cartilage damage ${ }^{[24]}$. Furthermore, previous studies reported that when in vitro healthy chondrocytes were exposed to the synovial fluid of osteoarthritic patients, they underwent apoptosis ${ }^{[25]}$.

The synovial membrane showed a significant increase in the area percentages of collagen fibers in toluidine blue stained sections. These results were explained by some authors who found that collagen synthesis was increased in $\mathrm{OA}$ in a rat model. They reported that synovial fibroblast cells were stimulated to produce excessive collagen fibers $^{[9]}$.

The articular cartilage of the knee joint of PRP treated OA group (subgroup IIC) showed a smooth surface with no erosions and the matrix was continuous with no fissures. The chondrocytes appeared occupying their lacunae and were organized into layers as in subgroup IA. Also, the color density of toluidine blue stain was significantly increased in comparison to OA groups (subgroups IIA and IIB). These findings were similar to those observed by some authors who found that the majority of joints injected with PRP had normal morphology with a smooth surface ${ }^{[9]}$. Moreover, the higher extent of cartilage regeneration and increased production of glycosaminoglycans in the matrix after PRP injection, suggesting that PRP could inhibit the catabolic effect of collagenase or stimulate the anabolic response of the damaged cartilage ${ }^{[26]}$. In addition, PRP could improve structure of the cartilage and slow the progression of $\mathrm{OA}$ by maintaining the balance between anabolism and catabolism in osteoarthritic patients and increased proteoglycan and type II collagen content ${ }^{[27]}$. The regenerative role of PRP injection had been explained by the physiological role of platelets that produce bioactive proteins responsible for attracting macrophages and mesenchymal stem cells facilitating tissue regeneration and promote scavenging of necrotic tissue ${ }^{[28]}$. It was proved that PRP increased hyaluronic acid concentration, stabilizing angiogenesis in patients with osteoarthritis ${ }^{[28]}$. The most pro-inflammatory cytokine IL-1 could be inhibited by $\mathrm{PRP}^{[29]}$. Also, platelets in PRP could release anti-inflammatory cytokines, including interleukin-1 receptor antagonist and soluble tumor necrosis factor receptor. Interleulin-1 receptor antagonist could inhibit the bioactivity of IL-1 by blocking its receptors. Soluble tumor necrosis factor receptor could bind to free TNF $\alpha$, thereby preventing signal transduction ${ }^{[30]}$.

The synovial membrane of PRP treated OA group (subgroup IIC) revealed thin intimal lining and few inflammatory cells. These findings were in accordance with many authors who reported that the synovium in PRP treated OA arthritis in rats showed an improvement in the form of a decrease in inflammatory cell infiltration and mild flattening of epithelial lining. They explained that PRP might attenuate the subsequent inflammatory response in $\mathrm{OA}^{[9]}$.

Platelet derived growth factor (PDGF) was expressed in the synovial membrane of all groups: control, OA and PRP treated OA groups. There was a positive immune staining with various degree in the synovial lining layer and in the endothelium of the blood vessels. The expression of PDGF in the synovial membrane was in coordination with other authors ${ }^{[9]}$. The significant increase in positive immune staining of PDGF after induction of OA was matched by previous studies that reported that the regenerative effect of PDGF in cartilage was attributed to the role of PDGF in wound healing or stimulation of matrix synthesis ${ }^{[31]}$. Platelet derived growth factor had a significant stimulatory effect on matrix production as it caused increased proliferation of the chondrocytes and increased production of extracellular matrix $^{[32]}$.

The significantly higher immune-stained area percentages for PDGF expression after PRP injection could be attributed to the findings that platelets contained an abundant amount of growth factors that were an important role in healing of soft tissue and bone mineralization ${ }^{[33]}$. The regenerative role of PDGF was either due to its mitogenic effect to the mesoderm-derived cells such as fibroblasts and chondrocytes or to its specific activities in angiogenesis and chemotaxis for fibroblasts and collagen synthesis ${ }^{[1]}$.

Platelet rich plasma injection was more effective in treatment of patients with mild knee joint OA, multiple intra-articular PRP knee injections (two to four injections) improved functional outcome scores at a minimum of 24 weeks ${ }^{[34]}$. On the other hand, the association of PRP with hyaluronic acid was effective and safe in the management of patients suffering from mild to moderate Knee joint $\mathrm{OA}^{[8]}$. Moreover, a recent study reported significant improvement in knee stiffness in patients with mild to moderate OA when given $5 \mathrm{~mL}$ PRP at monthly intervals for six months (six injections). Maximal improvement was seen in patients with young age, less weight short disease 
duration $^{[35]}$. Meanwhile, recent study proved that the intraarticular injection of PRP could inhibit inflammation and prevent progressive cartilage degeneration in a goat OA model, and these effects were more effective when associated with bone marrow concentrate ${ }^{[36]}$.

\section{CONCLUSION}

Intra-articular injection of PRP could effectively restore the structure of articular cartilage and synovial membrane of the knee joint of the rats of subgroup IIC (PRP treated OA group).

\section{RECOMMENDATION}

Intra-articular PRP injection might represent a promising new therapeutic strategy that assists the repair of the articular cartilage; further studies are recommended to investigate the effect of repeated intra-articular PRP injection and for longer duration. Moreover, concomitant administration of PRP and intra-articular corticosteroids, hyaluronic acid or stem cells might lead to hopeful results in severe knee joint osteoarthritis.

\section{ACKNOWLEDGEMENT}

This work was supported by Ain Shams University, Faculty of Medicine, Grants Office, Grant NO 47/2017.

\section{CONFLICTS OF INTEREST}

There are no conflicts of interest.

\section{REFERENCES}

1. Civinini R, Nistri L, Martini C, Redl B, Ristori G (2013): Growth factors in the treatment of early osteoarthritis. Clin Cases Miner Bone Metab 10: 26-29.

2. De Campos GC, De Rezende MU, Pailo AF (2012): Current concepts in osteoarthritis. Acta Ortop Bras, 21(2): 120-122.

3. Lozada C and Steigelfest E (2010): Osteoarthritis. Medicine Rheum, 15: 12-33.

4. Lckinger C, Rheum C, Tikly M (2010): Current approach to diagnosis and management of osteoarthritis. Division of Rheumatology, Chris Hani, Baragwaneth Hospital and University of the Witwatersrand and Johannesburg, 52 (5): 382-390.

5. Mc Carrel TM, Mall NA, Lee AS, Cole BJ and Butty DC (2014): Consideration for the use of platelet rich plasma in orthopedics. Sports Med 44 (8): 1025-1036

6. Sun Y, Feng Y, Zhang CQ, Chen SB and Cheng $X G$ (2010): The regenerative effect of platelet rich plasma on healing in large osteochondral defects. Int Orthop. 34:589-597.

7. Alcaraz JJ, Oliver AA, Sánchez JM and Lajara JJ (2015): Platelet rich plasma in regenerative medicine. Med Sci Rev, 2: 111-120.
8. Guo Y, Yu H, Yuan L, Yao S, Wang P, Lv H, Li W, Sun S (2016): Treatment of knee osteoarthritis with platelet-rich plasma plus hyaluronic acid in comparison with platelet-rich plasma only. Int J Clin Exp Med;9(6):12085-12090.

9. Almasry SM, Soliman HM, Ragab EM, Algaidi SAand El-Tarhouny SA (2014): Platelet rich plasma enhances the immunohistochemical expression of platelet derived growth factor and and vascular endothelial growth factor in the synovium of the meniscectomized rat models of osteoarthritis. Annals of Anatomy-Anatomischer Anzeiger, 197: 38-49.

10. Labusca LS and Cionca D (2016): Clinical Review about the role of platelet rich plasma for treatment of traumatic and degenerative musculoskeletal disorders. Ortho \& Rheum, 2 (3): 555-588.

11. Kalbkhani M, Dehghani SN, Naji Haddadi S, Najafpour AR, Ghorbanzadeh N and Kalbkhani MH (2015): Preventive role of platelet rich plasma in experimentally induced osteoarthritis in rabbit's knee joint. Ash Ese Journal of medicine and medical researches.1(4): 16-22.

12. Kamel NS, Arafa MM, Nadim A, Amer H, Amin IR, Samir N and Salem A (2014): Effect of intraarticular injection of mesenchymal stem cells in cartilage repair in experimental animals. The Egyptian Rheumatologist . 36 (4): 179-186.

13. Bancroft J.D., Gamble M. (2008): Theory and Practice of Histological Techniques, 6th edition, Churchill. Livingstone/Elsevier, Philadelphia.

14. Schmitz N, Lavertyz S, Krausx VB and Aignerk T (2010): Basic methods in histopathology of joint tissues. Osteoarth Cartil; 18 :113-116.

15. Juhl C, Christensen R, Roos EM, Zhang W, Lund H (2014): Impact of exercise type and dose on pain and disability in knee osteoarthritis: a systematic review and meta-regression analysis of randomized controlled trials. Arthritis Rheumatol, 66 (3): $622-36$

16. Makhlouf NA, Khalil WF and Lamiaa MF (2013): The possible therapeutic effect of 'Chaetomiumglobosum' fungal extract on experimentally induced rheumatoid arthritis. Egypt J Histo; 36 (3): 01-15.

17. Palmieri B, Rottigni V, Iannitti T (2013): Preliminary study of highly cross-linked hyaluronic acid-based combination therapy for management of knee osteoarthritis-related pain. Drug Des Devel Ther, 7: 7-12.

18. Li J, Hu Y, Ruoxi L, Ye Y, Wenxiang C, and Peng Z (2014): Attenuation of Collagen-Induced 
Arthritisin Rat by Nicotinic Alpha7 Receptor Partial Agonist GTS-21. Bio Med Res Inter Article; $8(2) ; 1-9$.

19. Palmer D, Strain W.D and Webb B (2014): Turning of the Tide: Does Tide mark Advancement Perpetuate Osteoarthritis. (2014): Rheumatology, Volume 53, Issue suppl_1, Pages i150.

20. Soliman, Nevine Bahaa E (2012): Effect of intraarticular injection of high-molecular-weight versus low-molecular-weight hyaluronic acid on the articular cartilage structure in experimentally induced knee joint osteoarthritis in albino rats. Egyptian Journal of Histology, 35 (3): 483-495.

21. Stannus O, Jones G, Cicuttini F, Parameswaran V, Quinn S, Burgess J, Ding C (2010): Circulating levels of IL- 6 and TNF- $\alpha$ are associated with knee radiographic osteoarthritis and knee cartilage loss in older adults. Osteoarthritis Cartilage, 18 (11): 1441-7.

22. Ashraf S, Mapp PI, Walsh DA(2011): Contributions of angiogenesis to inflammation, joint damage, and pain in a rat model of osteoarthritis. Arthritis Rheum; 63 (9): 2700-10.

23. Ng CT, Biniecka M, Kennedy A, McCormick J, Fitzgerald O, Bresnihan B, Buggy D, Taylor CT, O'Sullivan J, Fearon U, Veale DJ (2010): Synovial tissue hypoxia and inflammation in vivo. Ann Rheum Dis. 69 (7): 1389-95.

24. Adán N, Guzmán-Morales J, Ledesma-Colunga MG, Perales-Canales SI, Quintanar-Stéphano A, López-BarreraF, Méndez I, Moreno-Carranza B, Triebel J, Binart N, Martínez de la Escalera G, Thebault S and Clapp C (2013): Prolactin promotes cartilage survival and attenuates inflammation in inflammatory arthritis. J Clin Invest. 123 (9): 3902-3913.

25. Hoff $P$, Buttgereit F, Gerd-Rüdiger B, Jakstadt M, Gaber T, Andreas K, Matzioli G, Perka C, and Röhner E (2013): Osteoarthritis synovial fluid activates pro-inflammatory cytokines in primary human chondrocytes. Int Orthop, 37 (1): 145-151.

26. Dhillon MS, Behera P, Patel S and Shetty V (2014): Orthobiologics and platelet rich plasma. Indian J Orthop, 48 (1): 1-9.

27. Khoshbin A, Leroux T, Wasserstein D, Marks P, Theodoropoulos J, Ogilvie-Harris D, Gandhi
R, Takhar K, Lum G, Chahal (2013): The efficacy of platelet rich plasma in the treatment of symptomatic knee osteoarthritis: a systematic review with quantitative synthesis. Arthroscopy, 29 (12): 2037-48.

28. Anitua E, Sánchez M, Aguirre JJ, Prado R, Padilla S, Orive G (2014): Efficacy and safety of plasma rich in growth factors intra-articular infiltrations in the treatment of knee osteoarthritis. Arthroscopy, 30 (8): 1006-17.

29. Huang G, Hua S, Yang T, Ma J, Yu W, Chen X (2018): Platelet-rich plasma shows beneficial effects for patients with knee osteoarthritis by suppressing inflammatory factors. Exp Ther Med, 15 (3): 3096-3102.

30. Bendinelli P, Matteucci E, Dogliotti G, Corsi MM, Banfi G, Maroni P, Desiderio MA (2010): Molecular basis of anti-inflammatory action of platelet rich plasma on human chondrocytes: mechanisms of NF-kappa B inhibition via HGF. J Cell Physiol, 225: 757-766.

31. Sundman EA, Cole BJ, Fortier LA (2011): Growth factor and catabolic cytokine concentrations are influenced by the cellular composition of platelet rich plasma. Am J Sports Med. 39(10): 2135-40.

32. Malemud CJ (2010): Anticytokine therapy for osteoarthritis: evidence to date. Drugs Aging, 1;27 (2): 95-115.

33. Xie X, Zhang C, and Tua RS (2014): Biology of platelet-rich plasma and its clinical application in cartilage repair. Arthritis Res Ther, 16 (1): 204.

34. Filardo G, Matteo B, Martino A (2015): Plateletrich plasma intra-articular knee injections show no superiority versus viscosupplementation: a randomized controlled trial. Am J Sports Med. 43(7): $1575-82$.

35. Dhillon MS, Patel S, and John R (2017): PRP in OA knee - update, current confusions and future options. SICOT J. 3 (27).

36. Wang Z, Zhai C, Fei H, Hu J, Cui W (2018): Intra-articular injection autologous plateletrich plasma and bone marrow concentrate in a goat osteoarthritis model. Journal of Orthopedic Research, 36 (8). 


\title{
الملخص العربى
}

\section{الدور العلاجي المحتمل للبلازما الغنية بالصفائح الاموية على نموذج التهاب

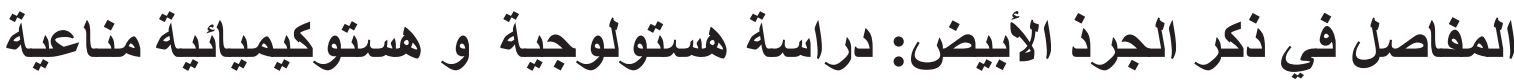

\author{
نيبال جمال عبد الوهاب، نجلاء مدحت إبراهيم ابو رابيه، فايقة حسن كامل الإبياري، \\ جيهان خلف مجاهد حسن، منى حسين رأفت

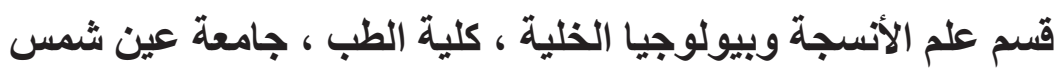

المقدمة والهُف من هذا العمل: التهاب المفاصل هو مرض تنكسي يتميز بآلام في المفاصل وفقد تدريجي للغضروف المفصلي ـ وقد صمدت هذه الدر اسة لتقييم الدور العلاجي للبلازما الغنية بالصفائح الدموية على مفصل الركبة في نموذج التهاب المفاصل في الجرذ . المواد وطرق البحث: في هذه الدر اسة تم استخدام أربعين من ذكور الجرذان البيضاء البالغة التي تزن 250-200 جر اما وتم استخدام عشر جرذان للحصول على البلازما الغنية بالصفائح الدموية وتم تقسيم باقي الجرذان إلى مجمو عتين رئيسيتين: المجموعة الأولى (المجمو عة الضابطة): تكونت من 15 من الجرذان وتم تقسيمها إلى 3 مجمو عات فرعية: المجموعة الأولى أ: مكونة من 5 جرذان تركت بدون أي تدخل وتم التضحية بها بعد 4 أسابيع من بداية التجربة. المجموعة الأولى ب: مكونة من 5 جرذان تركت بدون أي تدخل وتم التضحية بها بعد 6 أسابيع من بداية التجربة. المجمو عة الأولى ج: مكونة من 5 جرذان تركت لمدة 4 أسابيع ثم أخذت حقن البلازما الغنية بالصفائح الدموية (20.2 مل) داخل مفصل الركبة اليمين ثلاث مر ات أسبو عيا لمدة أسبو عين ثم تم التضحية بها. المجموعة الثانية (مجموعة التهاب المفاصل (: مكونة من 15 من الجرذان , تعرضت لعملية جر احية لإحداث التهاب المفاصل وتم تقسيم الجرذان إلى 3 مجمو عات فرعية: المجموعة الثانية أ: مكونة من 5 جرذان تم التضحية بها بعد 4 أسابيع من الجر احة. المجموعة الثانية ب: مكونة من 5 جرذان تم التضحية بها بعد 6 أسابيع من الجراحة. المجموعة الثانية ج: مكونة من 5 جرذان التي أخذت حقن البلازما الغنية بالصفائح الدموية (0.2 مل) داخل مفصل الركبة اليمين بعد 4 أسابيع من الجراحة وتكرر الحقن ثلاث مر ات أسبو عيا لمدة أسبو عين ثم تم التضحية بها وفي نهاية التجربة نم التضحية بكل الجرذان وتم تشريح مفاصل الركبة اليمين من جميع المجموعات وقد تم إزالة الكالسيوم منها وخضعت للار اسات الهستولوجية وقد تمت

معالجة العينات أيضا للفحص بالمجهر الالكتروني النافذ وتم إجر اء القياسات المورفومترية والإحصائية. نتائج البحث: أظهرت الدر اسة الهستولوجية لمجموعة الجرذان المصابة بمرض التهاب المفاصل (المجموعة الفرعية الثانية أ و المجموعة الفرعية الثانية ب) زيادة سمك البطانة الداخلية للغشاء الزليلي, تخلل خلوي وزيادة في كمية 
الكو لاجين. بالإضافة إلى ظهور ثاكل في السطح مع نقص في سمك الغضروف وفقد للخلايا و المصفوفة الغضروفية وقد كان الظهور معتدلا لعامل النمو المشتق من الصفائح الدموية. أما المجمو عة التي عولجت بالبلازما الغنية بالصفائح الدموية فقد تحسن تركيب الغثاء الزليلي والغضروف المفصلي وكان الظهور قويا لعامل النمو المشنق من الصفائح الدموية. الخلاصة: أن حقن البلازما الغنية بالصفائح الدموية داخل المفصل أدى بشكل فعال إلى استعادة التركيب الهستولوجي

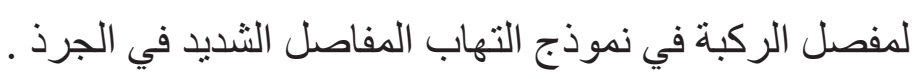

